\title{
Polityka gospodarcza w deklaracjach wyborczych kandydatów na Urząd Prezydenta Rzeczypospolitej Polskiej w 2010 roku
}

$\mathbf{Z}$ godnie z kalendarzem wyborczym jesienią 2010 roku miały się odbyć w Polsce wybory prezydenckie oraz samorządowe. Katastrofa lotnicza pod Smoleńskiem, śmierć Prezydenta RP - Lecha Kaczyńskiego ${ }^{1}$ spowodowały, że Marszałek Sejmu RP zgodnie z ustawą o wyborze prezydenta RP był zobowiązany do zarządzenia wyborów na ten urząd. Wybory te zostały przeprowadzone w trybie przyspieszonym.

21 kwietnia 2010 roku marszałek Sejmu RP pełniący obowiązki prezydenta Polski ${ }^{2}$ Bronisław Komorowski wydał postanowienie o przeprowadzeniu wyborów ${ }^{3}$. Data została wyznaczona na 20 czerwca 2010 roku, co oznaczało, iż ewentualna druga tura musiała się odbyć dwa tygodnie później.

Państwowa Komisja Wyborcza (PKW) zarejestrowała siedemnaście komitetów wyborczych $^{4}$, które do 6 maja miały prawo zgłaszać kandydatów na prezydenta ${ }^{5}$. Zarejestrowanych zostało dziesięć osób ubiegających się o ten urząd ${ }^{6}$ (załącznik).

Celem artykułu jest zaprezentowanie aspektu ekonomicznego deklaracji wyborczych kandydatów na Urząd Prezydenta Polski w ostatnich wyborach. Przedstawiono różnice i podobieństwa programów gospodarczych kandydatów, jednocześnie starano się odpowiedzieć na pytanie, które z obietnic kandydatów w zakresie polityki gospodarczej przyczyniły się do zwiększenia ich elektoratu, a także tych, które były przyczyną konfliktu między nimi.

Konstytucja RP daje prezydentowi Polski ograniczony wpływ na politykę gospodarczą. Może on korzystać z weta prezydenckiego lub odsyłać ustawy do Trybunału Konstytucyjnego $^{7}$. Wykorzystanie tych prerogatyw może jednak skuteczne blokować rządowe reformy gospodarcze. Stąd polityka gospodarcza jest jednym z elementów programów wyborczych

\footnotetext{
${ }^{1}$ Prezydent RP L. Kaczyński zginął w katastrofie lotniczej 10 kwietnia 2010 r. pod Smoleńskiem, udając się na uroczyste obchody siedemdziesiątej rocznicy zbrodni katyńskiej. Na pokładzie samolotu znajdowała się żona prezydenta oraz osoby pełniące najważniejsze funkcje w państwie, m.in. dowódcy sił zbrojnych, duchowni, politycy, przedstawiciele Rodzin Katyńskich. W katastrofie zginęło 96 osób. J. Cieśla, M. Kołodziejczyk, C. Łazarewicz, B. Mikołajewska, M. Papuzińska, J. Podgórska, P. Pytlakowski, J. Wilczak, E. Wnuk, Ostatni lot, „Polityka” 2010, nr 16, s. 5-7.

${ }^{2}$ Zob. art. 128 ust 2. Konstytucja Rzeczypospolitej Polskiej, Warszawa 2007, s. 34

${ }^{3}$ Postanowienie Marszałka Sejmu Rzeczypospolitej Polskiej z dnia 21 kwietnia 2010 r. o zarzadzeniu wyborów Prezydenta Rzeczypospolitej Polskiej, Dz. U. 2010, Nr 65, poz. 405.

${ }^{4}$ http://www.newsweek.pl/artykuły/sekcje/polska/pkw-zarejestrowała-17 komitetów..., 5.08.2010.

${ }^{5}$ Kandydata na prezydenta RP zgłaszali obywatele posiadający prawo wyborcze. Obwieszczenie Marszałka Sejmu Rzeczypospolitej Polskiej z dnia 22 kwietnia 2010 r. w sprawie ogłoszenia jednolitego tekstu ustawy o wyborze Prezydenta Rzeczypospolitej Polskiej, Dz. U. 2010, Nr 72, poz. 467.

${ }^{6}$ Komitetom wyborczym Gabriela Janowskiego, Krzysztofa Mazurskiego, Zdzisława Podkańskiego, Romana Sklepowicza, Bogdana Szpryngiela, Ludwika Wasiaka, Józefa Wójcika nie udało się zebrać wymagającej liczby głosów poparcia (co najmniej 100 tys. podpisów), tym samym nie zostali zarejestrowani przez PKW. http://www.newsweek.pl/artykuły/sekcje/polska/pkw-zarejestrowała-17 komitetów..., 5.08.2010.

${ }^{7}$ Zob. art. 122. Konstytucja Rzeczypospolitej..., op. cit., s. 35-36.
} 
pretendentów na ten urząd. Wymiar ekonomiczny programów wyborczych był tematem rozmów kandydatów z wyborcami oraz debat. Założenia polityki gospodarczej wiązały się z wizją Polski kandydatów.

Podczas kampanii prezydenckiej najwięcej uwagi poświęcono prywatyzacji szpitali. Przyszłość polskiej służby zdrowia wywoływała emocje i była przyczyną sporu między kandydatami. Bronisław Komorowski opowiadał się za przekształceniem szpitali w spółki prawa handlowego, które następnie zostałyby poddane procesowi naprawczemu. Usługi w skomercjalizowanych ośrodkach medycznych miały być nieodpłatne.

Jarosław Kaczyński bardzo ogólnie mówił na temat przyszłości szpitali. Zdaniem prezesa PiS służba zdrowia powinna być publiczna i sprawnie funkcjonować. 9 czerwca 2010 r. podczas wiecu w Lublinie Kaczyński zarzucił kandydatowi PO, że dąży do sprywatyzowania publicznych szpitali. Powiedział: sprawa stużby zdrowia, prywatna, sprywatyzowana - takjak chce mój główny polityczny konkurent - czy też publiczna dla niektórych, zależna od portfela, czy dla wszystkich [...]. Kartka wyborcza wrzucona 20 czerwca jest albo za tym, albo za tym ${ }^{8}$. Wypowiedź ta spowodowała, że sztab wyborczy Komorowskiego złożył pozew w trybie wyborczym przeciwko liderowi PiS za mówienie i rozpowszechnianie kłamstwa o prywatyzacji służby zdrowia9. Sąd Okręgowy w Warszawie uznał, iż Kaczyński dopuścił się kłamstwa i manipulacji, przypisując Komorowskiemu chęć sprywatyzowania służby zdrowia. Sąd apelacyjny podtrzymał orzeczenie sądu pierwszej instancji ${ }^{10}$.

W odpowiedzi na wyrok sądu sztab wyborczy kandydata PiS zaproponował Komorowskiemu debatę poświęconą reformie służby zdrowia. Kandydat PO odniósł się przychylnie do tej propozycji, stawiając jednak warunki - wykonania wyroku sądu oraz rozszerzenia tematów debaty ${ }^{11}$. W spór między Bronisławem Komorowskim a Jarosławem Kaczyńskim włączyli się inni kandydaci ubiegający się o fotel prezydenta. Grzegorz Napieralski zwrócił się do obu kandydatów, by wydali oficjalne oświadczenia w sprawie komercjalizacji i prywatyzacji szpitali $^{12}$. Zdaniem kandydata Sojuszu Lewicy Demokratycznej (SLD) rozwiałoby to wszelkie wątpliwości co do ich poglądów w tak bardzo istotnej dla polskiego społeczeństwa sprawie. Jednocześnie przewodniczący SLD opowiedział się za równym i bezpłatnym dostępem do opieki zdrowotnej dla wszystkich obywateli. Był przeciwny komercjalizacji i prywatyzacji szpitali publicznych. Podobne stanowisko w sprawie przyszłości służby zdrowia zajęli Waldemar Pawlak, Andrzej Lepper, Marek Jurek, Bogusław Ziętek i Kornel Morawiecki. Kandydaci podkreślali, że istotne jest, aby publiczna służba zdrowia funkcjonowała sprawnie. Zdaniem Pawlaka i Leppera działalność publicznych szpitali nie powinna ograniczać możliwości powstawania prywatnych placówek ${ }^{13}$. Waldemar Pawlak przywołał podobne rozwiązania istniejące $\mathrm{w}$ systemie oświaty. Prowadzenie działalności przez publiczne i prywatne placówki medyczne stworzyłoby możliwość podwyższenia ich usług. Kandydat Samoobrony RP za przyczynę zapaści gospodarczej szpitali podał brak środków finansowych na leczenie pacjentów. W związku z tym zaproponował zawieszenie długów i określenie przyczyn złej

\footnotetext{
8 „Gazeta Wyborcza”, 16.06.2010.

${ }^{9}$ Ibidem.

${ }^{10}$ Sąd Okręgowy w Warszawie nakazał komitetowi J. Kaczyńskiego sprostowanie wypowiedzi lidera PiS dotyczącej prywatyzacji służby zdrowia jako jednego z założeń programu gospodarczego B. Komorowskiego. „,Rzeczpospolita", 23.06.2010.

${ }^{11}$ Debata poświęcona służbie zdrowia między J. Kaczyńskim i B. Komorowskim nie odbyła się.

${ }^{12} \mathrm{http}: / /$ prywatnezdrowie.pl/artykuly/poradnik-pacjenta/kandydaci-na-prezydenta-rp-20..., 6.08.2010.

${ }^{13} \mathrm{http} / /$ www.tvn24.pl/1,1658533,druk.html, 6.08.2010.
} 
kondycji finansowej placówek, a następnie przeznaczenie środków na ich oddłużanie ${ }^{14}$. Niezależny kandydat Andrzej Olechowski nie był jednoznacznie przeciwny prywatyzacji służby zdrowia. Uważał, że zmiana właściciela powinna być przeprowadzona tylko tam, gdzie byłaby niezbędna ze względu na interes pacjenta i rachunek ekonomiczny placówki. W swoim programie Kontrakt dla Polski obiecał wyborcom, iż pomoże stworzyć polityczny konsensus wokót reformy systemu ochrony zdrowia. Musimy i możemy mieć stużbę zdrowia, na której można polegać! Ważnq zasadq nowego systemu winna być konkurencja zarówno ubezpieczycieli, jak i jednostek świadczacych ustugi medyczne. Wszyscy obywatele będa mieć zapewniony dostęp do sprawnej stużby zdrowia - tak aby każdy mógt się leczyć $w$ dobrej placówce niezależnie od jej formy prawnej ${ }^{15}$.

Przewodniczący Wolności i Praworządności Janusz Korwin-Mikke opowiadał się za likwidacją publicznych szpitali i tym samym Ministerstwa Zdrowia ${ }^{16}$. Jego zdaniem tylko istnienie prywatnej służby zdrowia spowodowałoby, że opieka medyczna kosztowałaby kilkakrotnie mniej niż obecnie.

Większość kandydatów na Urząd Prezydenta RP opowiadała się za zwiększeniem nakładów finansowych na służbę zdrowia. Zdaniem Komorowskiego powinny one wzrastać stopniowo, w miarę możliwości budżetowych państwa ${ }^{17}$. Prezes PiS oraz przewodniczący SLD zauważyli, że wzrost środków finansowych na usługi medyczne wpłynie na ich wyższy poziom ${ }^{18}$. Z kolei Pawlak przewidywał obniżenie cen leków, łatwiejszy dostęp do nowoczesnych metod terapeutycznych w wyniku zwiększenia środków budżetowych na opiekę medyczną ${ }^{19}$.

Przewodniczący Prawicy Rzeczpospolitej Marek Jurek zakładał wzrost wydatków publicznych na ochronę zdrowia w wyniku starzenia się społeczeństwa. Mówił o tym, że państwo powinno na ten cel przeznaczyć $6 \% \mathrm{PKB}^{20}$. Odmienne stanowisko w tej kwestii miał Korwin-Mikke. W jego opinii środki na leczenie powinny pochodzić od pacjentów, a nie z budżetu państwa ${ }^{21}$. Tym samym wybór lekarza oraz placówki medycznej miał być uzależniony od decyzji pacjenta.

Podczas kampanii mniej uwagi poświęcono systemowi podatkowemu niż reformie służby zdrowia. Kandydaci niechętnie wypowiadali się na ten temat. Waldemar Pawlak, Marek Jurek, Andrzej Lepper oraz Kornel Morawiecki nie przedstawili konkretnych zmian podatkowych. Zwolennikiem podatku liniowego byli Bronisław Komorowski oraz Andrzej Olechowski. Kandydat PO zapowiedział, że większość parlamentarna, opowie się za zmianą podatku progresywnego na liniowy ${ }^{22}$. Olechowski opowiadał się za wprowadzeniem podatku liniowego, zaznaczając, że jest to korzystne rozwiązanie pod względem efektywności ekonomicznej państwa. Jednocześnie zaznaczył, że zmiany podatkowe polegające na wprowadzeniu jednolitej stawki podatkowej przez pierwsze dwa lata zmniejszyłyby dochody państwa ${ }^{23}$, a następnie

${ }^{14} 15$ czerwca 2010 r. w Warszawie A. Lepper zorganizował konferencję prasową przed Szpitalem Klinicznym im. W. Orłowskiego, podczas której przedstawił swoje stanowisko odnośnie sytuacji w służbie zdrowia, http://www.newsweek.pl/artykuły/lepper-\%E2\%80\%9Edlugi_luzby_zdrowia..., 6.08.2010.

${ }^{15} \mathrm{http}: / /$ www.olechowski.pl/program/show/id/6, 6.08.2010.

${ }^{16} \mathrm{http}: / /$ www.polskieradio.pl/jedynka/sygnalydnia/print.aspx?id=21930, 6.08.2010.

${ }^{17} \mathrm{http} / / /$ www.tvn24.pl/1,1658533,druk.htm, 6.08.2010.

${ }^{18}$ Ibidem.

${ }^{19}$ Ibidem.

${ }^{20}$ Ibidem.

${ }^{21} \mathrm{http}$ ://www.polskieradio.pl/jedynka/sygnalydnia/print.aspx?id=21930, 6.08.2010.

22 „Gazeta Wyborcza”, 18.05.2010.

${ }^{23}$ Ibidem. 
doszłoby do ich zwiększenia. W tej sytuacji zmiana systemu podatkowego, przy istniejącym deficycie budżetowym, nie powinna być celem priorytetowym w zakresie polityki gospodarczej $^{24}$. Jednocześnie zapowiedział, że jeżeli zostanie wybrany na prezydenta, to nie pozwoli na podwyżkę podatków ${ }^{25}$. Grzegorz Napieralski krytycznie ocenił zmianę systemu progresywnego na liniowy. Swoje stanowisko argumentował mniejszymi dochodami do budżetu państwa. Opowiadał się za opodatkowaniem Kościoła, wprowadzeniem podatku kościelnego na wzór niemiecki i przywróceniem trzeciego progu w skali PIT $^{26}$. Jarosław Kaczyński w swoim programie wyborczym bardzo ogólnie poruszył kwestie związane z systemem podatkowym. Podkreślił znaczenie systemu prawnego i podatkowego, od którego zależy wysokość stopy bezrobocia. Prezes PiS, podobnie jak Bronisław Komorowski, był zwolennikiem zniesienia podatku Belki ${ }^{27}$. Odmienne stanowisko w tej kwestii miał Olechowski ${ }^{28}$.

Janusz Korwin-Mikke opowiadał się za likwidacją podatku dochodowego, CIT, pozostawieniem podatku od towarów i usług (VAT) oraz akcyzy ${ }^{29}$. Zamiast podatku dochodowego zaproponował podatek pogłówny, który miałby być przeznaczony na utrzymanie wojska i policji ${ }^{30}$. Zdaniem prezesa Wolności i Praworządności wysokość pozostałych podatków należało zmniejszyć siedmiokrotnie.

Inne rozwiązania w systemie podatkowym przewidywał Bogusław Ziętek. Zaproponował wprowadzenie lokalnego podatku w wysokości 10 zł, który byłby przekazywany do budżetu gmin i powiatów, w celu pomocy finansowej miejscowym placówkom służby zdrowia.

Kandydaci na prezydenta, oprócz Olechowskiego, ogólnie wypowiadali się na temat przedsiębiorczości. Również w ich programach wyborczych niewiele uwagi poświęcono tej kwestii.

Zdaniem Komorowskiego politycy nie powinni ,przeszkadzać” przedsiębiorcom, ale dbać o rozwój gospodarczy państwa, dążyć do jego odbiurokratyzowania oraz zwiększyć przepływ osiagnięć nauki do biznesu. Podczas II Europejskiego Kongresu Gospodarczego w Katowicach kandydat PO ocenił polską gospodarkę jako kraj przyjazny biznesowi. Ludziom skłonnym inwestować swoje pieniqdze musi dodawać optymizmu fakt, iż do niedawna Polska byta jedyna ,zielona wyspa" w czasie kryzysu, jedynym krajem, który osiagnat dodatni wzrost gospodarczy i obronit swoja gospodarkę przed kryzysem ${ }^{31}$. Jarosław Kaczyński starał się nie tylko oceniać polską gospodarkę, ale również przedstawić jej kierunki rozwoju. Prezes PiS uważał, że przyszłość polskiej gospodarki jest uzależniona od ludzkiej inicjatywy i przedsiębiorczości ${ }^{32}$. W związku z tym obiecał wprowadzenie ułatwień dla przedsiębiorców, między innymi reaktywować Pakiet Kluski ${ }^{33}$, uprościć procedury uzyskiwania przez przedsiębiorców

24 Ibidem.

${ }^{25}$ Ibidem

${ }^{26}$ „Dziennik Gazeta Prawna”, 1.06.2010.

${ }^{27}$ W roku 2002 minister finansów Marek Belka wprowadził podatek od zysku z lokat bankowych (zwany potocznie podatkiem Belki). Zyski z lokat bankowych zostały oprocentowane 19-procentowym podatkiem. „Gazeta Wyborcza", 28.07.2009.

${ }^{28}$ Ibidem i ,Dziennik Gazeta Prawna”, 1.06.2010.

29 ,Rzeczpospolita”, 17.06.2010.

${ }^{30} \mathrm{http} / /$ korwin-mikke.blog.onet.pl/Jeszcze-o-podatkach,2,ID388871084,n, 6.08.2010.

${ }^{31}$ II Europejski Kongres Gospodarczy w Katowicach odbył się 31 maja-2 czerwca 2010 roku, Europejski Kongres Gospodarczy 2010, „Nowy Przemysł” 2010, nr 7-8, s. 5.

32 „Gazeta Wyborcza”, 14.05.2010.

33 Program gospodarczy Pakiet Kluski został opracowany przez rząd Kaczyńskiego w marcu 2007 r. Dokument ten zawierał zbiór projektów ustaw, które miały stworzyć przedsiębiorcom lepsze warunki do rozwoju przedsiębiorczości. W wyniku przyspieszonych wyborów parlamentarnych oraz powołania gabinetu Donalda Tuska Pakiet Kluski nie został przyjęty przez parlament. Szerzej M. Kamola-Cieślik, Założenia i realizacja programu gospodarczego 
pozwoleń na budowę, zmniejszyć okres przechowywania rachunków pochodzących z kas fiskalnych oraz znowelizować Kodeks pracy ${ }^{34}$. 1 lipca 2010 roku Kaczyński, uczestnicząc w Kongresie Przedsiębiorczości, zapowiedział, że jako prezydent zmniejszy liczbę koncesji z przeszło 400 do 25 oraz przygotuje projekt ustawy podobny do ustawy ministra Wilczka z końca lat osiemdziesiątych ${ }^{35}$, który znosiłby wszelkie bariery w gospodarce i ułatwiłby rozwój przedsiębiorczości ${ }^{36}$.

Grzegorz Napieralski, Waldemar Pawlak, Andrzej Lepper, Marek Jurek, podobnie jak Jarosław Kaczyński, opowiedzieli się za wspomaganiem przedsiębiorczości przez uproszczenie procedur w zakresie przyznawania pozwoleń na zakładanie firm oraz ich działalnośćc ${ }^{37}$. W opinii lidera SLD takie działania miały wyeliminować ryzyko rozwoju korupcji. Kandydat

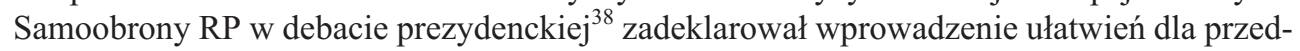
siębiorców, dzięki którym miały być tworzone nowe miejsca pracy, głównie dla ludzi młodych ${ }^{39}$. Marek Jurek chciał wspierać przedsiębiorców przez politykę podatkową.

W programie wyborczym Andrzeja Olechowskiego dużo uwagi poświęcono sprawom związanym z rozwojem polskich firm. Bezpartyjny kandydat obiecał wykorzystać swoje kontakty oficjalne i osobiste, aby zwiększyć napływ zagranicznych kontraktów i inwestycji oraz promować polskie firmy za granica ${ }^{40}$. Zapewniał, iż jako prezydent będzie zajmować się promocją przedsiębiorczości w celu podniesienia jej społecznego prestiżu oraz powoła rzecznika przedsiębiorczości, którego zadaniem będzie dbanie o jej rozwój ${ }^{41}$. Olechowski, odwołując się do swojego programu, stwierdził, że Prezydent może bardzo dużo. Może wprowadzić klimat sprzyjajacej przedsiębiorczości, koncentracji na sprawach gospodarczych. Może być doświadczonym partnerem rzqdu przy przeprowadzeniu ważnych inicjatyw, może przypilnować sprawy ustawodawstwa dotyczqcego przedsiębiorczości, która jest w Polsce strasznie „,zabagniona". Prezydent może również zagwarantować, że przez 5 lat nie podniesie podatków, wówczas cała polityka rzadu musi się skoncentrować na reformach ${ }^{42}$.

Liberalne rozwiązania dotyczące rozwoju przedsiębiorczości prezentował Janusz Korwin-Mikke. Był przeciwny ingerencji rządu, prezydenta w działalność przedsiębiorstw, co może hamować rozwój firm i przyczyniać się do ich upadku. Zadaniem państwa powinno być kontrolowanie przedsiębiorstwa w zakresie przestrzegania prawa. W opinii przewodniczącego partii Wolność i Praworządność najlepsze rozwiązania legislacyjne w zakresie rozwoju przedsiębiorczości zostały ujęte w ustawie Wilczka. Zatem kandydat na prezydenta opowiadał się za jej reaktywowaniem.

Prawa i Sprawiedliwości w latach 2005-2007, w: Partie polityczne-przywództwo partyjne, red. J. Sileski, M. Czerwiński, Toruń 2008, s. 217-218.

34 „Dziennik Gazeta Prawna”, 8.06.2010.

${ }^{35}$ Ustawa o działalności gospodarczej z 1988 roku (potocznie zwana ustawą Wilczka) autorstwa ówczesnego ministra przemysłu Mieczysława Wilczka w rządzie Mieczysława Rakowskiego umożliwiała podejmowanie i prowadzenie działalności gospodarczej na równych prawach wszystkim, co spowodowało aktywizację drobnych przedsiębiorców. Ustawa z dnia 23 grudnia 1988 r. o działalności gospodarczej, Dz. U. 1988, Nr 41, poz. 324.

${ }^{36}$ M. Wilczek, do którego odwoływał się prezes PiS, zaapelował do przedsiębiorców, by głosowali na Komorowskiego, ponieważ Kaczyński kojarzy mu się ze wszystkim, tylko nie przedsiębiorczościq, „Gazeta Wyborcza”, 2.07.2010.

${ }^{37} \mathrm{http}: / /$ wyborcza.biz/biznes/2029020,101562,8009606.htm?, 7.08.201.

388 czerwca 2010 r. odbyła się debata prezydencka, w której uczestniczyli A. Lepper, K. Morawiecki i B. Ziętek. http://wiadomości.wp.pl/drukuj.html?wid=1234701, 7.08.2010.

${ }^{39} \mathrm{http}: / /$ www.polskieradio.pl/prezydent2010/wiadomosci/artykul16467.html, 7.08.2010.

${ }^{40} \mathrm{http}: / /$ www.olechowski.pl/program/show/id/6, 7.08.2010.

41 Wybory 2010, „Polityka” 2010, nr 25, s. 11.

42 http://www.rdc.pl/index.php?/pol/artykuly_2/gosc_rdc/andrzej_olechowski_kandyd..., 7.08.2010. 
Kandydaci na prezydenta RP Bogusław Ziętek i Kornel Morawiecki zapowiedzieli stworzenie miejsc pracy dla ludzi młodych. Przewodniczący Polskiej Partii Pracy i Wolnego Związku Zawodowego „Sierpień 80” obiecał stworzenie preferencyjnych warunków dla przedsiębiorców, którzy zatrudnialiby młode osoby ${ }^{43}$. Działania te miały spowodować spadek bezrobocia oraz rozwój polskich firm.

Przystąpienie Polski do unii walutowej było jednym z zagadnień, które zostało poruszone przez pretendentów na Urząd Prezydenta RP między innymi podczas debat prezydenckich, spotkań z wyborcami oraz wywiadów przygotowanych przez tygodnik „Wprost” i dziennik „Gazeta Wyborcza”. Wśród kandydatów brakowało jednomyślności co do kwestii wejścia Polski do strefy euro. Zwolennikiem przyjęcia tej waluty byli: Komorowski, Kaczyński, Napieralski, Pawlak, Olechowski, Ziętek ${ }^{44}$. Przeciwne stanowisko prezentowali: Korwin-Mikke, Lepper, Jurek. Z kolei Morawiecki nie chciał wypowiadać się na ten temat, dopóki kryzys gospodarczy w Grecji nie zostanie opanowany przez państwa UE.

W pierwszych tygodniach kampanii Bronisław Komorowski wypowiadał się jedynie ogólnie na temat przyjęcia Polski do strefy euro. 26 maja 2010 roku kandydat PO w wywiadzie dla „Dziennika Gazety Prawnej” powiedział: do strefy euro powinniśmy dołaczyć wówczas, gdy gospodarka europejska będzie się rozwijała szybciej od polskiej, bo wtedy członkostwo w tym klubie będzie niosło nas w górę ${ }^{45}$. Kilka dni później, uczestnicząc w II Europejskim Kongresie Gospodarczym w Katowicach, a następnie w telewizyjnej debacie prezydenckiej ${ }^{46}$, opowiedział się za przystąpieniem Polski do strefy euro w perspektywie czternastu, szesnastu lat $^{47}$. Kandydat PO obiecał wspierać polski rząd w realizacji tego celu.

Jarosław Kaczyński, Grzegorz Napieralski, Waldemar Pawlak oraz Andrzej Olechowski opowiedzieli się za przyjęciem waluty euro przez Polskę pod warunkiem sprzyjającej sytuacji makroekonomicznej kraju ${ }^{48}$. Zdaniem polityków przystapienie do strefy euro powinno nastapić nie wcześniej niż po 2015 roku. Prezes PSL stwierdził, iż decyzja o wprowadzeniu europejskiej waluty powinna być uzależniona od poziomu jej kursu. Zwrócił także uwagę na korzyści wynikające z przystąpienia Polski do strefy euro ${ }^{49}$. Niezależny kandydat uważał, iż przyjęcie tej waluty ustabilizuje polską gospodarkę, zlikwiduje negatywne skutki wahań kursu złotówki oraz zwiększy dyscyplinę budżetową. Ziętek był przeciwny szybkiemu wprowadzeniu euro, gdyż mogłoby to niekorzystnie wpłynąć na polską gospodarkę. W związku z tym kandydat na prezydenta RP nie podał terminu jej przyjęcia ${ }^{50}$.

Prezes partii Wolność i Praworządność Janusz Korwin-Mikke był przeciwny przystapieniu Polski do unii walutowej, zwracając uwagę, że tylko złotówka może być gwarantem poprawy elastyczności polskiej gospodarki ${ }^{51}$. Zdaniem Andrzeja Leppera przystapienie do strefy euro powodowałoby wzrost cen, co wpłynęłoby na poziom życia społeczeństwa. Sceptycyzm Marka Jurka wobec przyjęcia przez Polskę euro wynikał z dysproporcji rozwoju

\footnotetext{
${ }^{43} \mathrm{http}: / /$ www.bankier.pl/wiadomosci/print.html?article_id=2157629, 7.08.2010.

44 Debata prezydencka 2010 we ,,Wprost”, „Wprost”' 2010 , nr 22, s. 14.

45 „Dziennik Gazeta Prawna”, 26.05.2010.

4613 czerwca 2010 r. odbyła się telewizyjna debata prezydencka z udziałem Komorowskiego, Kaczyńskiego, Napieralskiego i Pawlaka, „Gazeta Wyborcza”, 14.06.2010.

47 „Dziennik Gazeta Prawna”, 15.05.2010; „Gazeta Wyborcza”, 1.06.2010.

48 M. Krzymowski, Walka z mitem, „Wprost” 2010, nr 19, s. 10; http://www.wprost.pl/ar/196163/Debata-prezydencka-2010-we-Wprost-cz-I-Gospodarka..., 7.08.2010.

${ }^{49}$ Ibidem.

${ }^{50}$ http://www.tvn24.pl/1,1658535,druk.html, 7.08.2010.

${ }^{51}$ Ibidem.
} 
państw należących do unii walutowej oraz konieczności wspierania konkurencyjności polskich firm za pomocą własnej waluty ${ }^{52}$.

Przed drugą turą wyborów prezydenckich jednym z głównych problemów poruszanych przez kandydatów były założenia polityki rolnej. Zaprezentowanie programu oraz sposobu jego realizacji miało na celu pozyskanie głosów rolników przez pretendentów na Urząd Prezydenta RP. Wizja rozwoju polskiej wsi została wykorzystana przez Komorowskiego jako środek do ataku na swojego głównego kontrkandydata. 28 czerwca 2010 roku w ostatnich minutach debaty telewizyjnej kandydat PO zarzucił Kaczyńskiemu, że udzielając wywiadu dla tygodnika „European Voice”, opowiedział się za likwidacją dopłat rolnych w celu utworzenia silnej europejskiej armii ${ }^{53}$. Prezes PiS zaprzeczył tym oskarżeniom i zapowiedział podjęcie działań mających na celu zrównanie dopłat dla polskich rolników z tymi, jakie obowiązywały między innymi we Francji i w Niemczech. Kaczyński obiecał zlikwidować dysproporcje rozwoju między miastem a wsią. W rozmowie z przedstawicielami kółek rolniczych lider PiS podkreślił, iż stawia na rozwój wsi z wielu powodów, także ze względu na to, że jest zwolennikiem idei spójności narodu ${ }^{54}$. Kandydat PO obiecał natomiast powołać forum środowisk wiejskich przy prezydencie. Do jego zadań należałoby prowadzenie dyskusji i wypracowanie rozwiązań, na podstawie których prezydent mógłby skuteczniej nakłaniać rząd i parlament do realizacji konkretnych rozwiązań z zakresu polityki rolnej ${ }^{55}$.

Pomoc środowiskom wiejskim, a szczególnie rolnikom produkującym zdrową żywność, zadeklarował również Waldemar Pawlak ${ }^{56}$. Prezes PSL, podobnie jak Kaczyński, Napieral$\mathrm{ski}^{57}$, Lepper i Olechowski ${ }^{58}$, opowiedział się za zwiększeniem środków unijnych dla rolników i polepszeniem sytuacji na polskiej wsi. Zdaniem Napieralskiego prezydent powinien współdziałać z rządem i parlamentem na rzecz zrównania szans rozwoju polskiego rolnictwa z rolnictwem w innych państwach UE. Korwin-Mikke, Jurek, Ziętek oraz Morawiecki w programach wyborczych oraz podczas kampanii nie odwoływali się do elektoratu wiejskiego.

W dokumentach wyborczych kandydatów zabrakło również odniesienia się do roli prezydenta w zakresie zwiększenia bezpieczeństwa energetycznego kraju. Liderzy sondaży wyborczych: Komorowski, Kaczyński, Napieralski i Pawlak swoje stanowiska w zakresie polityki bezpieczeństwa państwa zaprezentowali między innymi w debacie telewizyjnej ${ }^{59}$. Pozostali kandydaci nie wypowiadali się na ten temat. Uczestnicy debaty do priorytetowych celów polskiej polityki gospodarczej zaliczyli zagwarantowanie dostaw źródeł energii. Kandydat PO za gwarancje bezpieczeństwa energetycznego Polski uważał członkostwo w UE oraz budowę Gazoportu, uzyskiwanie energii z węgla, elektrowni atomowych i ze złóż łupkowych. Prezes PiS opowiedział się za poprawą dywersyfikacji dostaw energii. Uznał za błąd polskiej polityki rządu uzależnienie się od jednego dostawcy gazu. Wielkie nadzieje pokładał w wykorzystaniu gazu łupkowego, twierdząc, że jest to szansa, że Polska stanie się druga Norwegia, krajem, który będzie mógt korzystać i z punktu widzenia ekonomicznego, ale także politycznego, bo to jest zmiana sytuacji geopolitycznej $w$ tej części Europy ${ }^{60}$. Odmienne stanowisko

\footnotetext{
${ }^{52}$ http://www.wprost.pl/ar/196163/Debata-prezydencka-2010-we-Wprost-cz-I-Gospodarka..., 7.08.2010.

53 „Gazeta Wyborcza”, 29.06.2010.

${ }^{54} \mathrm{http} / /$ www.kolkarolnicze.eu/nprint.php?Nid=113, 8.08.2010.

${ }^{55}$ Ibidem.

${ }^{56} \mathrm{http} / / /$ www.prezydentpawlak.eu/upload/obrazki/PROGRAM/WP_03.jpeg, 8.08.2010.

${ }^{57} \mathrm{http}: / /$ www.napieralski.com.pl/program, 8.08.2010.

${ }^{58} \mathrm{http}: / /$ suwalki.naszemiasto.pl/drukuj/454424, w-suwalkach-andrzej-lepper-namawial-..., 8.08.2010.

59 „Gazeta Wyborcza”, 14.06.2010.

${ }^{60} \mathrm{http}: / / w w w . w n p . p l / d r u k u j / 112316 \_1 . h t m l, 8.08 .2010$.
} 
$\frac{\sqrt{\pi}}{\frac{\pi}{2}}$

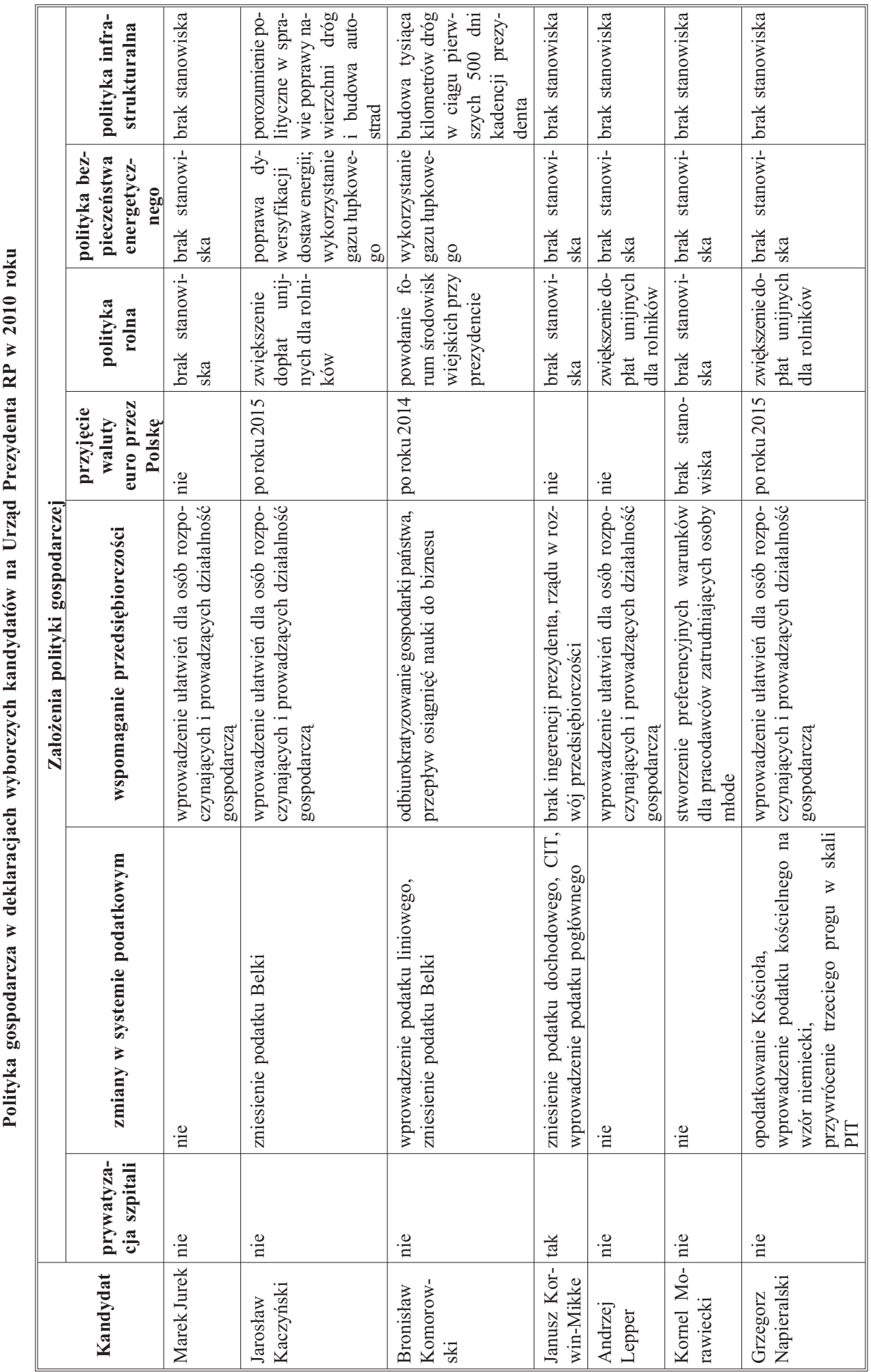




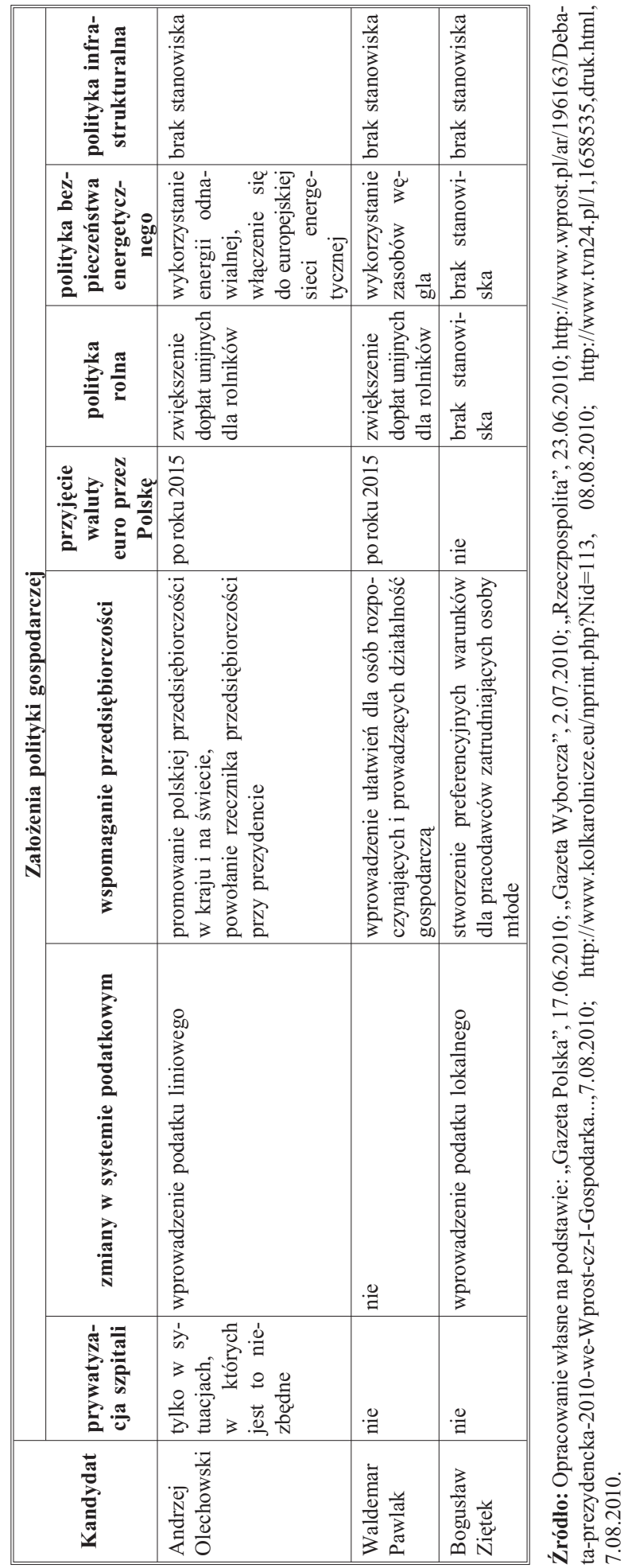


w sprawie bezpieczeństwa energetycznego prezentował Napieralski. Zdaniem lidera SLD kontrakty podpisane przez Polskę na dostawy gazu ziemnego w pełni gwarantowały jej bezpieczeństwo. Alternatywą dla umów międzynarodowych miała być energia odnawialna oraz włączenie się do europejskiej sieci energetycznej ${ }^{61}$. Kandydat ludowców określił Polskę jako jedno $\mathrm{z}$ bezpieczniejszych energetycznie państw UE $\mathrm{z}$ uwagi na zasoby węgla ${ }^{62}$.

Rozwój infrastruktury drogowej był przedmiotem obietnic wyborczych kandydata PO. Działania te były związane z pozyskaniem niezdecydowanego elektoratu. W ostatnim dniu kampanii Komorowski zapowiedział, że jeśli zostanie prezydentem, to $w$ ciagu pierwszych 500 dni kadencji rozpocznie budowę tysiaca kilometrów nowych dróg ${ }^{63}$. Bardziej powściagliwy w swoich wypowiedziach był Kaczyński. Jego zdaniem problemy administracyjne były przyczyną złego stanu nawierzchni dróg i małej liczby autostrad. Poprawę stanu polskiej infrastruktury drogowej uzależniał od porozumienia politycznego $\mathrm{w}$ tej sprawie ${ }^{64}$. Pozostali kandydaci nie wypowiadali się na temat infrastruktury.

Kampania prezydencka przebiegała w cieniu katastrofy smoleńskiej. Od samego jej początku było wiadomo, iż największe szanse na zwycięstwo w wyborach będą mieli Bronisław Komorowski i Jarosław Kaczyński ${ }^{65}$. Świadczyły o tym wyniki sondaży przeprowadzanych między innymi przez Ośrodek Badania Opinii Publicznej (OBOP).

20 czerwca 2010 roku liczba uprawnionych do głosowania wyniosła 30813 005, oddano 16923832 głosów, z czego ważnych było 16806 170. Frekwencja wyborcza wyniosła $54,94 \%{ }^{66}$. Liczbę uzyskanych głosów przedstawiono w tabeli 2 . Dwa tygodnie później odbyła się druga tura wyborów. W głosowaniu wzięło udział 17050417 osób, oddano 16853021 głosów ważnych. Frekwencja wyborcza wyniosła 55,31\%. Bronisław Komorowski uzyskał 8933887 głosów (53,01\%), a Jarosław Kaczyński 7919134 (46,99\%) ${ }^{67}$.

Tabela 2

Wyniki pierwszej tury wyborów na prezydenta Polski 20 czerwca 2010 roku

\begin{tabular}{|r|l|c|c||}
\hline \hline Lp. & \multicolumn{1}{|c|}{ Imię i nazwisko } & Liczba glosów & Procent glosów \\
\hline 1 & Bronisław Komorowski & 6981319 & 41,54 \\
\hline 2 & Jarosław Kaczyński & 6128255 & 36,46 \\
\hline 3 & Grzegorz Napieralski & 2299870 & 13,68 \\
\hline 4 & Janusz Korwin-Mikke & 416898 & 2,48 \\
\hline 5 & Waldemar Pawlak & 294273 & 1,75 \\
\hline 6 & Andrzej Olechowski & 242439 & 1,44 \\
\hline 7 & Andrzej Lepper & 214657 & 1,28 \\
\hline 8 & Marek Jurek & 177315 & 1,06 \\
\hline 9 & Bogusław Ziętek & 29548 & 0,18 \\
\hline 10 & Kornel Morawiecki & 21596 & 0,13 \\
\hline
\end{tabular}

Źródło: http://prezydent2010.pkw.gov.p1/PZT1/PL/WYN/W/index.htm, 9.08.2010.

\footnotetext{
${ }^{61}$ Ibidem.

${ }^{62} \mathrm{http} / / /$ wybory.wp.pl/kat,1329,page,2wid,12364426,wiadomosc.html, 8.08.2010.

${ }^{63} \mathrm{http}: / /$ www.dziennik.pl/drukowanie/270232, 8.08.2010.

${ }^{64} \mathrm{http}: / /$ www.wnp.pl/drukuj/111898_1.html, 8.08.2010.

65 J. Paradowska, Barwy kampanii: sepia i czerń, „Polityka” 2010, nr 19, s. 13.

${ }^{66} \mathrm{http} / /$ prezydent2010.pkw.gov.pl/PZT1/PL/WYN/W/index.htm, 9.08.2010.

${ }^{67}$ Ibidem; Połowa Polaków dała Platformie czerwonq kartkę. Politycy o wyborach prezydenckich, „Gazeta Polska” 2010, nr 27, s. 4.
} 
Założenia polityki gospodarczej w programach wyborczych kandydatów na Urząd Prezydenta Polski w roku 2010 zostały zaprezentowane w sposób bardzo ogólny. Wyjątkiem był Kontrakt dla Polski Olechowskiego, który jako jedyny spośród kandydatów odwoływał się między innymi do przedsiębiorców i rolników oraz podkreślał, że jako prezydent będzie koncentrował się na gospodarce.

Problemy gospodarcze były przedmiotem deklaracji kandydatów podczas spotkań z wyborcami i debat telewizyjnych. Najwięcej uwagi poświęcono prywatyzacji, systemowi podatkowemu oraz rozwojowi przedsiębiorczości. Wizja polskiej gospodarki przedstawiona przez kandydatów była podobna. Jedynie Korwin-Mikke opowiadał się za jak najmniejszym interwencjonizmem państwa w życie gospodarcze. Komercjalizacja placówek służby zdrowia oraz dopłaty unijne dla rolników były przedmiotem sporu między Komorowskim i Kaczyńskim. Wygrana Komorowskiego w sądowym sporze o prywatyzację służby zdrowia nie wpłynęła na pozyskanie przez niego niezdecydowanego elektoratu, o czym świadczyły wyniki sondaży przedwyborczych.

Komorowski został wybrany na prezydenta Polski niewielką różnicą głosów. Przegrana Kaczyńskiego była związana z posiadanym przez niego większym elektoratem negatywnym. Kandydat PiS był postrzegany przez wyborców Komorowskiego jako polityk konfliktowy nieuznający kompromisów pomimo, iż podczas kampanii nawoływał do zgody i unikał ostrych wypowiedzi.

\section{Załącznik}

\section{Kandydaci ubiegający się o Urząd Prezydenta RP w 2010 roku}

JUREK MAREK (lat 50) - lider Prawicy Rzeczypospolitej. Ukończył studnia historyczne na Uniwersytecie Adama Mickiewicza w Poznaniu ${ }^{68}$. W roku 1989 współtworzył Zjednoczenie Chrześcijańsko-Narodowe ${ }^{69}$, w którym pełnił funkcję wiceprezesa i przewodniczącego Rady Naczelnej. Był posłem na Sejm PRL X kadencji oraz posłem na Sejm RP I, IV i V kadencji ${ }^{70}$. W latach 1995-2001 członek Krajowej Rady Radiofonii i Telewizji (KRRiT), a w roku 1995 jej przewodniczący. W styczniu 1998 roku Jerzy Buzek jako premier rządu powołał go na członka Rady ds. Reform Ustrojowych Państwa. W roku 2001 roku współtworzył Przymierze Prawicy, które rok później zjednoczyło się z partią Prawo i Sprawiedliwość (PiS). Następnie pełnił funkcję wiceprezesa PiS ${ }^{71}$. Od października 2005 do kwietnia 2007 roku - marszałek Sejmu RP. W kwietniu 2007 r. zrezygnował z członkostwa w PiS i utworzył chrześcijańsko-konserwatywną partię polityczną Prawica Rzeczypospolitej. W roku 2007 ubiegał się o mandat do Senatu RP, a rok później do Parlamentu Europejskiego (PE), których nie uzyskał ${ }^{72}$.

KACZYŃSKI JAROSŁAW ALEKSANER (lat 61) - kandydat PiS. Doktor nauk prawnych Wydziału Prawa i Administracji Uniwersytetu Warszawskiego ${ }^{73}$. Od lat siedemdziesiątych

\footnotetext{
${ }^{68}$ Opozycja w PRL. Słownik biograficzny 1956-1989, red. J. Skórzyński, Warszawa 2000, s. 135-136.

${ }^{69}$ M. Czajka, M. Kamler, W. Sienkiewicz, Leksykon historii Polski, Warszawa 1991, s. 291.

${ }^{70} \mathrm{http}: / /$ orka.sejm.gov.pl/ArchAll2.nsf/Glowny5kad, 5.08.2010.

${ }^{71} \mathrm{http}: / /$ www.marekjurek.pl/omnie, 5.08.2010.

$72 \mathrm{http} / /$ wybory.onet.pl/prezydenckie-2010/kandydaci/jurek-marek,1333,kandydat.html, 5.08.2010.

${ }^{73} \mathrm{http}: / /$ jaroslawkaczynski.info/jaroslaw_kaczynski/Notka_biograficzna, 5.08.2010.
} 
zaangażowany w działalność opozycyjną ${ }^{74}$. Współpracował między innymi z Komitetem Obrony Robotników (KOR) ${ }^{75}$ i Komitetem Helsińskim. W roku 1989 uczestniczył w obradach okrągłego stołu oraz w powołaniu rządu Tadeusza Mazowieckiego, reprezentując Niezależny Samorządny Związek Zawodowy „Solidarność” (NSZZ „Solidarność”) ${ }^{76}$. W tym też roku otrzymał mandat senatora, a następnie był posłem na Sejm RP I, III, IV, V i VI kadencji $^{77}$. W latach 1990-1992 pełnił funkcję szefa Kancelarii Prezydenta Lecha Wałęsy. W roku 1990 współtworzył Porozumienie Centrum (PC), którego był prezesem przez osiem lat. W roku 2001 wraz z bratem Lechem Kaczyńskim powołał Prawo i Sprawiedliwość, dwa lata później został przewodniczącym partii ${ }^{78}$. W roku 2005, w wyborach do Sejmu RP, partia Kaczyńskiego odniosła zwycięstwo. Wbrew powszechnym oczekiwaniom prezes PiS nie objął stanowiska premiera. Dopiero w lipcu 2006 roku po dymisji gabinetu Kazimierza Marcinkiewicza podjął się misji tworzenia rządu.

Nieoficjalnym kandydatem PiS w wyborach prezydenckich 2010 roku był prezydent Lech Kaczyński. Jego kandydatura miała zostać ogłoszona podczas kongresu partii. Śmierć Prezydenta wymusiła na partii wybranie innego kandydata, którym został Jarosław Kaczyński ${ }^{79}$.

KOMOROWSKI BRONISŁAW MARIA (lat 58) - kandydat Platformy Obywatelskiej. Ukończył historię na Uniwersytecie Warszawskim. W latach siedemdziesiątych współpracował z KOR-em, Ruchem Obrony Praw Człowieka i Obywatela. W roku 1989 został dyrektorem gabinetu Aleksandra Halla w Urzędzie Rady Ministrów ${ }^{80}$. W latach 1990-1993 pełnił funkcję cywilnego wiceministra obrony narodowej ds. wychowawczo-społecznych w rządzie Tadeusza Mazowieckiego, Jana Krzysztofa Bieleckiego, Hanny Suchockiej ${ }^{81}$. W rządzie Józefa Buzka stał na czele resortu obrony narodowej. Poseł na Sejm RP I, II, III, IV, V i VI kadencji ${ }^{82}$. W roku 2005 został wicemarszałkiem Sejmu RP, a w 2007 roku - marszałkiem. Był związany z Unią Demokratyczną (UD), Unią Wolności (UW) oraz ze Stronnictwem Konserwatywno-Ludowym, Akcją Wyborczą Solidarność (AWS) ${ }^{83}$. Od roku 2001 członek zarządu krajowego PO, a od 2006 jej wiceprzewodniczący. Po śmierci prezydenta L. Kaczyńskiego, będąc marszałkiem Sejmu RP, pełnił obowiązki prezydenta $\mathrm{RP}^{84}$. W marcu 2010 roku został kandydatem PO na Urząd Prezydenta RP, pokonując w prawyborach Radosława Sikorskiego ${ }^{85}$.

KORWIN-MIKKE JANUSZ RYSZARD (lat 68) - lider partii Wolność i Praworządność. Absolwent Wydziału Matematyki i Filozofii na Uniwersytecie Warszawskim. Był aresztowany i relegowany z Uniwersytetu Warszawskiego za udział w wydarzeniach marcowych

${ }^{74}$ Opozycja w PRL..., op.cit., s. 139.

${ }^{75}$ M. Czajka, M. Kamler, W. Sienkiewicz, op. cit., s. 293.

${ }^{76}$ Ibidem.

${ }_{77}^{77} \mathrm{http}: / /$ www.sejm.gov.pl/poslowie/posel6/137htm, 5.08.2010.

${ }^{78} \mathrm{http}: / /$ jaroslawkaczynski.info/jaroslaw_kaczynski/Notka_biograficzna, 5.08.2010.

79 „Gazeta Wyborcza”, 27.04.2010; J. Żakowski, PiS oddaje prezesa, „Polityka” 2010, nr 18, s. 18.

${ }^{80} \mathrm{http} / /$ www.bronislawkomorowski.pl/o-mnie.html, 5.08.2010.

${ }^{81}$ Opozycja w PRL..., op. cit., s. 172-174.

$82 \mathrm{http}: / /$ www.bronislawkomorowski.pl/o-mnie.html, 5.08.2010.

${ }^{83}$ Ibidem.

${ }^{84}$ Zob. art. 131 ust. 2. Konstytucja Rzeczypospolitej..., op. cit., s. 34, J. Paradowska, Państwo po katastrofie, „Polityka" 2010, nr 16, s. 11-13.

${ }^{85}$ W. Smoczyński, Armata na uwięzi, „Polityka” 2010, nr 10, s. 20-23. 
w 1968 roku $^{86}$. W latach 1962-1982 członek Stronnictwa Demokratycznego (SD), a od 1984 roku Partii Liberałów „Prawica”. W roku 1987 powołał i był prezesem Ruchu Polityki Realnej, który został przekształcony w Unię Polityki Realnej, a następnie w Konserwatywno-Liberalną Partię Unii Polityki Realnej. W latach 1990-1997 i 1999-2003 pełnił funkcję prezesa partii. Poseł na Sejm RP I kadencji ${ }^{87}$. W roku 2005 założył partię Platforma Obywatelska Janusza Korwin-Mikkego, która w 2009 zmieniła nazwę na Wolność i Praworządność. Bez powodzenia kandydował między innymi w wyborach parlamentarnych w latach 1993, 1997, 2001, prezydenckich - 1995, 2000 i $2005^{88}$ oraz do PE - w 2004 roku.

LEPPER ANDRZEJ ZBIGNIEW (lat 56) - kandydat Samoobrony RP. Absolwent Technikum Rolniczego w Sypniewie. W latach 1991-1993 inicjator powołania Związku Zawodowego Rolnictwa Samoobrona, a następnie partii Samoobrona RP ${ }^{89}$. W latach 1998-2001 sprawował mandat radnego Sejmiku Województwa Zachodniopomorskiego. Poseł na Sejm RP IV i V kadencji ${ }^{90}$. Od października do listopada 2001 r. oraz w latach 2005-2006 wicemarszałek Sejmu RP. W rządzie Kazmimierza Marcinkiewicza i Jarosława Kaczyńskiego sprawował urząd wicepremiera i ministra rolnictwa i rozwoju wsi. Ubiegał się o fotel prezydenta RP w latach 1995, 2000 i $2005^{91}$. Przeciwko niemu toczyło się wiele postępowań karnych, między innymi pod zarzutami pomówienia i zniewagi ${ }^{92}$.

MORAWIECKI KORNEL ANDRZEJ (lat 69) - kandydat Solidarności Walczącej. Doktor fizyki. W latach osiemdziesiątych opozycjonista, inspirator wrocławskich strajków w sierpniu '80, kierował działem wydawniczym Regionalnego Komitetu Strajkowego Dolny Śląsk ${ }^{93}$. W roku 1982 we Wrocławiu założył Solidarność Walczącą̨ ${ }^{94}$, organizację walczącą o upadek komunizmu, niepodległą i suwerenną Polskę. Przeciwnik porozumień okrągłego stołu. Bez sukcesu ubiegał się w 1991 roku o mandat posła, a w latach 1997 i 2007 senatora.

NAPIERALSKI GRZEGORZ BERNARD (lat 36) - przewodniczący SLD. Absolwent Wydziału Humanistycznego Uniwersytetu Szczecińskiego. W latach 1995-1999 pełnił funkcję sekretarza Socjaldemokracji Rzeczypospolitej Polskiej (SdRP) w Szczecinie. Po przekształceniu SdRP zaczął pełnić obowiązki przewodniczącego partii w województwie zachodniopomorskim $^{95}$. W roku 2004 został wiceszefem Rady Krajowej SLD, a rok później sekretarzem generalnym partii. W roku 2008, ubiegając się o przywództwo w partii, poko-

\footnotetext{
${ }^{86} \mathrm{http}: / /$ korwin-mikke.pl/strony/o_jkm, 5.08.2010.

${ }^{87} \mathrm{http}: / /$ orka.sejm.gov.pl/ArchAll2.nsf/Glowny1kad, 5.08.2010.

88 „Gazeta Wyborcza”, 27.04.2010.

${ }^{89} \mathrm{http} / / / \mathrm{www} . \mathrm{kw}$-andrzejaleppera,home.pl/index.html, 5.08.2010.

${ }^{90}$ Ibidem.

${ }^{91}$ Ibidem.

${ }^{92}$ W roku 2005 Lepper został skazany wyrokiem sądu za pomówienie Włodzimierza Cimoszewicza. Następnie Sąd Najwyższy wrócił do sprawy i umorzył ją z powodu przedawnienia. Decyzja sądu nie została odnotowana w Krajowym Rejestrze Prawnym, co spowodowało, że PKW odmówiła rejestracji Leppera jako kandydata na prezydenta w 2010 roku. W wyniku wyjaśnienia okoliczności tej sprawy PKW uchyliła swą wcześniejszą uchwałę o odmowie rejestracji A. Leppera jako kandydata na prezydenta Polski. http://www.gazetaprawna.pl/drukowanie/420393, 5.08.2010.

${ }^{93} \mathrm{http}: / /$ kornelmorawiecki-razem.pl/informacje, 5.08.2010.

${ }^{94}$ M. Czajka, M. Kamler, W. Sienkiewicz, op.cit., s. 401; http://www.sw.org.pl/index1.html, 6.08.2010.

$95 \mathrm{http} / /$ www.napieralski.com.pl/o-mnie, 6.08.2010.
} 
nał ówczesnego przewodniczącego Wojciecha Olejniczaka. Poseł na Sejm RP IV, V i VI kadencji ${ }^{96}$.

W kwietniu 2010 roku SLD poparł kandydaturę Napieralskiego w wyborach prezydenc$\mathrm{kich}^{97}$. Zastapił on tragicznie zmarłego w katastrofie lotniczej pod Smoleńskiem Jerzego Szmajdzińskiego, który w grudniu 2009 roku został ogłoszony kandydatem SLD w wyborach prezydenckich.

OLECHOWSKI ANDRZEJ MARIAN (lat 63) - bezpartyjny kandydat wspierany przez Stronnictwo Demokratyczne ${ }^{98}$. Doktor nauk ekonomicznych. W latach siedemdziesiątych i osiemdziesiątych pracował w sekretariacie Konferencji Narodów Zjednoczonych ds. Handlu i Rozwoju (UNCTAD) ${ }^{99}$. W latach 1988-1989 był dyrektorem departamentu w Ministerstwie Współpracy Gospodarczej z Zagranicą. Reprezentował stronę rządową w obradach okragłego stołu. W rządzie Jana Olszewskiego objął stanowisko ministra finansów, a w gabinecie Pawlaka - ministra spraw zagranicznych ${ }^{100}$. Był współzałożycielem Bezpartyjnego Bloku Wspierania Reform (BBWR) - w 1993 roku, Komitetu Stu - w 1995, PO - w $2001^{101}$. W lipcu 2009 roku został szefem Rady Programowej SD. Jego zadaniem było kierowanie pracami nad realizacją programu SD. Kandydował na Urząd Prezydenta RP w roku 2000.

PAWLAK WALDEMAR (lat 51) - prezes Polskiego Stronnictwa Ludowego (PSL). Absolwent Wydziału Samochodów i Maszyn Rolniczych Politechniki Warszawskiej. Swoją karierę polityczną rozpoczął w 1985 roku, wstępując do Zjednoczonego Stronnictwa Ludowego (ZSL) ${ }^{102}$. Z listy tego ugrupowania został wybrany do Sejmu kontraktowego. Następnie był posłem na Sejm RP I, II, III, IV, V i VI kadencji ${ }^{103}$. W latach 1991-1997 i od 2005 roku pełnił funkcję prezesa PSL. W roku 1992 został desygnowany przez prezydenta RP Lecha Wałęsę na urząd premiera. Jego misja tworzenia rządu zakończyła się niepowodzeniem $^{104}$. W roku 1993 ponownie objął stanowisko premiera, tworząc rząd koalicyjny Sojuszu Lewicy Demokratycznej i Polskiego Stronnictwa Ludowego (SLD-PSL) ${ }^{105}$.

W wyborach prezydenckich kandydował w 1995 roku. Pod koniec 2007 r. w wyniku zawarcia koalicji PO-PSL objął stanowisko wicepremiera i ministra gospodarki w rządzie Donalda Tuska.

ZIĘTEK BOGUSŁAW (lat 46) - kandydat Polskiej Partii Pracy i Wolnego Związku Zawodowego „Sierpień 80”,106. Ukończył technikum. Od roku 2005 prezes partii i przewodniczący związku. Współorganizator demonstracji przeciwko zamykaniu kopalń, hut oraz łamaniu praw pracowniczych w służbie zdrowia oraz hipermarketach.

${ }^{96}$ Ibidem.

97 „Gazeta Wyborcza”, 22.04.2010; „Rzeczpospolita”, 23.04.2010.

98 M. Krzymowski, op.cit., s. 13.

99 „Rzeczpospolita”, 13.05.2010.

100 K. Leszczyńska, Rzqdy Rzeczypospolitej Polskiej (1989-2005). Skład, organizacja i tryb funkcjonowania, Toruń 2007 , s. $123,127$.

${ }^{101} \mathrm{http}: / /$ www.olechowski.pl/content/show/id/1, 6.08.2010.

$102 \mathrm{http}: / /$ www.prezydentpawlak.eu/biografia, 6.08.2010.

${ }^{103}$ Ibidem.

${ }^{104}$ M. Czajka, M. Kamler, W. Sienkiewicz, op. cit., s. 552.

${ }^{105}$ Polityka gospodarcza w programach rzadów polskich z lat 1989-1997, wybór i opracowanie M. Kamola-Cieślik, Toruń 2009, s. 607-609.

${ }^{106} \mathrm{http}: / /$ wybory.onet.pl/prezydenckie-2010/kandydaci/zientek-bogusław, 1335,kandydat..., 8.09.2010. 


\section{Bibliografia}

\section{Źródła drukowane:}

Dziennik Ustaw RP (1988-2010).

Konstytucja Rzeczypospolitej Polskiej, Warszawa 2007.

Polityka gospodarcza w programach rzq̨ów polskich z lat 1989-1997, wybór i opracowanie M. Kamola-Cieślik, Toruń 2009.

\section{Prasa:}

„Dziennik Gazeta Prawna” (2010).

„Gazeta Polska”(2010).

„Gazeta Wyborcza” (2009-2010).

„Nowy Przemysł” (2010).

„Polityka” (2010).

„Rzeczpospolita” (2010).

„Wprost” (2010).

\section{Słowniki, leksykony:}

Czajka M., Kamler M., Sienkiewicz W., Leksykon historii Polski, Warszawa 1991.

Opozycja w PRL. Stownik biograficzny 1956-1989, red. J. Skórzyński, Warszawa 2000.

\section{Opracowania:}

Leszczyńska L., Rząy Rzeczypospolitej Polskiej (1989-2005). Skład, organizacja i tryb funkcjonowania, Toruń 2007.

Partie polityczne - przywództwo partyjne, red. J. Sileski, M. Czerwiński, Toruń 2008.

\section{Internet:}

http://jaroslawkaczynski.info.

http://kornelmorawiecki-razem.pl.

http://korwin-mikke.blog.onet.pl.

http://korwin-mikke.pl.

http://orka.sejm.gov.pl.

http://prywatnezdrowie.pl.

http://suwalki.naszemiasto.pl.

http://www.bankier.pl.

http://www.gazetaprawna.pl.

http://www.kolkarolnicze.eu.

http://www.kw-andrzejaleppera,home.pl.

http://www.marekjurek.pl.

http://www.napieralski.com.pl.

http://www.newsweek.pl.

http://www.olechowski.pl.

http://www.polskieradio.pl.

http://www.prezydentpawlak.eu.

http://www.sw.org.pl.

http://www.tvn24.pl.

http://www.wprost.pl.

http://wyborcza.biz/biznes.

http://wybory.onet.pl. 


\section{Summary}

\section{Polish economic policy in the election statements of candidates for the presidency in Poland in 2010}

The paper presents the differences and similarities in the economic platforms of candidates for presidency of Poland. An attempt is also made to assess which promises made by the candidates in the realm of economy generated support, and which were responsible for the conflicts arising between them. Economic problems were the subject of the electoral declarations of many candidates. Privatization, the tax system and the development of businesses attracted most attention. The visions of the Polish economy presented by the candidates were similar. Only Janusz Korwin-Mikke advocated a minimum of state intervention in economic life. The commercialization of the national health system and agricultural subsidies were the centre of the disputes between Bronisław Komorowski and Jarosław Kaczyński. The fact that the former won a judicial argument about the privatization of the health system did not help him to win over undecided voters, which was clearly evidenced in the opinion polls conducted before the election. Komorowski was elected Poland's president by a small majority. Kaczyński's defeat was due to the fact that he commanded a significant negative electorate. 